\title{
Analisis Pendampingan Literasi Budaya Dan Kewarganegaraan Di Era New Normal
}

\author{
Ima Wahyu Putri Utami' ${ }^{1)}$, Abdurrohman Muzakki ${ }^{2)}$ \\ ${ }^{1}$ Universitas Muhammadiyah Malang \\ Email: imawahyu@umm.ac.id \\ ${ }^{2}$ Universitas Muhammadiyah Malang \\ Email: $\underline{\text { muzakki@umm.ac.id }}$
}

\begin{abstract}
Abstrak
Tujuan penelitian ini adalah untuk mendapatkan gambaran literasi budaya dan kewarganegaraan yang dapat dilakukan di era new normal. Jenis penelitian yang digunakan dalam penelitian ini adalah penelitian kualitatif. Teknik pengumpulan data yang digunakan adalah wawancara, observasi, dan dokumentasi. Instrumen penelitian yang digunakan adalah pedoman wawancara, pedoman pengamatan, dan pedoman dokumentasi. Teknik analisis data yang digunakan adalah data yang diperoleh kemudian dianalisis, disajikan sesuai dengan formulasi masalah, dan kesimpulan yang ditarik. Hasil penelitian ini adalah pelaksanaan pendampingan diawali dengan pemberian workshop terkait literasi budaya dan materi kewarganegaraan, kemudian dilanjutkan dengan pendampingan melalui grup WhatsApp. Sedangkan untuk faktor pendukung kegiatan pendampingan ini, yaitu sekolah sangat menyambut baik dengan pendampingan ini, sedangkan faktor penghambatnya adalah karena kegiatan sekolah dilakukan secara online sehingga sangat bergantung pada sarana dan prasarana berbasis IT namun tidak semua guru menguasai IT. Sehingga dalam pelaksanaannya yang membutuhkan IT, guru yang belum menguasai IT berkolaborasi dengan guru yang pandai IT.
\end{abstract}

Kata kunci: Literasi Budaya dan Nasionalis, New Normal

\begin{abstract}
The purpose of this research is to get a picture of cultural literacy and citizenship that can be done in the new normal era. This type of research used in this research is qualitative research. Data collection techniques used were interviews, observation, and documentation. The research instruments used were interview guidelines, observation guidelines, and documentation guidelines. The data analysis technique used is the data obtained, then analyzed, presented by the formulation of the problem, and conclusions drawn. The result of this research is that the implementation of mentoring begins with providing workshops related to cultural literacy and citizenship material, then continued with assistance through the WhatsApp group. As for the supporting factors of this mentoring activity, namely the school is very welcome with this mentoring, while the inhibiting factor is because school activities are carried out online so that they depend heavily on IT-based facilities and infrastructure, but not all teachers master IT. So that in its implementation that requires IT, teachers who have not mastered IT collaborate with teachers who are good at IT.
\end{abstract}

Keywords: Cultural and National Literacy, New Normal

\section{PENDAHULUAN}

Berkaitan dengan stabilitas nasional, ada 2 ancaman bagi Indonesia. Yang pertama Indonesia sebagai negara kepulauan. Kedua, terbukanya negara yang mengakibatkan adanya pengaruh global masuk. Sehingga generasi muda perlu dibekali dengan kemampuan mengetahui segala hal yang beragam, menyesuaikan dan menyikapi segalanya secara bijak. Kemampuan ini perlu diawali dengan kesadaran akan berbudaya dan berkewarganegaraan. Salah satu langkah untuk menciptakan kesadaran tersebut yaitu dengan membiasakan literasi pada anak-anak usia sekolah dasar. Literasi budaya dan kewarganegaraan adalah kecakapan yang harus dimiliki oleh seluruh warga Indonesia 
WAHANA

Volume 72, Nomor 2, Desember 2020

Salah satu ciri bangsa yang besar yaitu ditandai dengan masyarakatnya yang literat, masyarakat yang memiliki peradaban tinggi, dan aktif memajukan masyarakat dunia. Literasi yang dimaksud dalam hal ini bukan hanya warga yang melek aksara, namun lebih pada bagaimana suatu bangsa memiliki kecakapan hidup untuk bersaing dengan negara lain. Dengan kata lain, semakin tinggi tingkat literasi suatu bangsa, maka semakin tinggi pula kemampuan bangsa untuk berkolaborasi dalam persaingan global.

Budaya literasi bangsa dapat dikembangkan melalui pintu utama yaitu dengan adanya kelengkapan buku atau bahan bacaan yang memadai serta niat minat baca anak yang meningkat. Minat baca anak adalah bagian hal terpenting untuk ditumbuhkan. Menumbuhkan minat baca dimulai dari keluarga. Keluarga adalah pondasi penting sebuah proses dari budaya literasi (Direktorat Pendas, 2016). Budaya literasi akan terus tumbuh jika didukung tersedianya bahan bacaan bermutu dan terjangkau. Karena dengan adanya modal bahan bacaan, maka akan menimbulkan kebiasaan membaca, menulis secara masif di lingkungan sekolah ataupun di masyarakat. Maka, perkembangan literasi budaya dan kewarganegaraan dapat terwujud apabila kemampuan dalam membaca secara dasar telah dipenuhi (Wina, 2005).

SDN Juwet II merupakan salah satu sekolah pemerintah yang berada di pinggiran Kabupaten Kediri. Sehingga update pendampingan mengenai perkembangan kebijakan jarak didapatkan. SDN Juwet II adalah salah satu sekolah yang jumlah muridnya tergolong sedikit, namun prestasi siswa tidak kalah dengan sekolah yang lainnya. Siswa SDN Juwet II selalu masuk dalam 3 besar dalam UN di Kecamatan Kunjang, Kabupaten Kediri. Dengan kondisi SDN tersebut namun memiliki potensi siswa yang cukup baik maka perlu dilakukan pendampingan-pendampingan terkait kebijakan-kebijakan baru dalam pendidikan, salah satunya terkait gerakan literasi budaya dan kewarganegaraan.

Berdasarkan hasil observasi dan wawancara pada tanggal 10 Januari 2020 jumlah guru SDN Juwet II yaitu 9 orang dengan rincian 6 Guru PNS dan 3 GTT. Semua guru di SDN Juwet II berpendidikan S1. Guru SDN Juwet II juga sangat terbuka dengan perkembangan pendidikan. Hal ini terlihat dengan antusiasnya guru dengan perkembangan pendidikan. Jumlah siswa di SDN Juwet II secara keseluruhan yaitu 64 siswa, dengan rincian: kelas I sebanyak 7 siswa, kelas II sebanyak 13 siswa, kelas III sebanyak 12 siswa, kelas IV sebanyak 13 siswa, kelas V sebanyak 11 siswa, dan kelas VI sebanyak 8 siswa. Mulai tahun 2011 sampai 2018 UN SDN Juwet II selalu mendapatkan peringkat 10 besar dari 22 SDN di Kecamatan Kunjang, terlebih pada tahun 2013/2014 mendapat peringkat 2, 2015/2016 mendapat peringkat 1 , dan pada tahun 2-17/2018 mendapat peringkat II.

SDN Juwet I sudah melaksanakan gerakan literasi sesuai himbauan Bupati Kediri yaitu membaca buku yang ada di sudut kelas. Namun pelaksanaan literasi hanya sebatas siswa diminta membaca buku yang telah disediakan di sudut kelas. Sementara pada masa pandemi seperti ini tidak memungkinkan siswa untuk datang ke sekolah untuk membaca buku. Sementara kegiatan pendidikan seharusnya juga tetap dapat berjalan. Berdasarkan permasalahan tersebut maka telah dilaksanakan pendampingan agar dapat memberikan wawasan yang luas bagi guru dalam pelaksanaan literasi khususnya literasi kebudayaan dan kewarganegaraan di tengah pandemi. Adapun rumusan masalah dari penelitian ini yaitu untuk mendapatkan gambaran literasi budaya dan kewarganegaraan yang dapat dilaksakan pada era new normal.

\section{METODE PENELITIAN}

Jenis penelitian ini yaitu penelitian kualitatif. Penelitian kualitatif bermaksud untuk memahami fenomena tentang apa yang dialami oleh subjek penelitian, misalnya perilaku, motivasi, persepsi dengan cara deskripsi dan memanfaatkan berbagai metode ilmiah (Sugiyono, 2014:5).

Data dalam penelitian ini didapat melalui observasi dan wawancara kepada guru serta dokumentasi. Data yang didapat selanjutnya dipilah-pilah dianalisis sesuai dengan rumusan masalah. Selanjutnya data disajikan dalam bentuk deskripsi sesuai dengan rumusan masalah.

Dalam penelitian ini yang terlibat yaitu tim peneliti guru kelas sebagai pelaksana literasi. Selain itu kepala sekolah sebagai penentu kebijakan di sekolah.

Instrumen pengumpulan data yang digunakan dalam penelitian ini yaitu pedoman wawancara, pedoman observasi dan dokumentasi. Ketiga instrumen tersebut digunakan untuk mendapatkan data yang valid sesuai dengan rumusan masalah (Marpaung, 2001). 
Teknik pengumpulan data yang digunakan dalam penelitian ini yaitu sesuai dengan instrumen pengumpulan data. Adapun teknik pengumpulan data tersebut yaitu dengan observasi. Observasi dilakukan untuk mengetahui proses pendampingan literasi budaya dan kewarganegaraan. Selanjutnya wawancara digunakan untuk mendapatkan data pendukung terkait dengan pendampingan literasi budaya dan kewarganegaraan. Sedangkan dokumentasi digunakan untuk memperkuat data yang didapat dengan observasi, foto hasil dokumentasi dapat memperkuat data yang telah dideskripsikan. Pada penelitian ini analisis data dilakukan mulai dari dilakukannya pengumpulan data. Teknik analisis data yang digunakan dalam penelitian ini yaitu model Miles Huberman. Adapun tahap analisis data menurur Miles (2014) yaitu: reduksi data (data reduction), penyajian data (data display) serta penarikan kesimpulan dan verifikasi (conclusion drawing/verification). Pada tahap reduksi data, data yang didapatkan disederhanakan dan digambarkan secara umum untuk mendapatkan informasi yang jelas, menyeluruh dan memudahkan dalam menjelaskan data. Selanjutnya tahap penyajian data dilakukan dalam bentuk penjelasan. Tahap selanjutnya yaitu penarikan kesimpulan dari data yang telah disajikan.

\section{HASIL DAN PEMBAHASAN}

Pendampingan yang dilakukan dalam pelaksanaan gerakan literasi kebudayaan dan kewarganegaraan yaitu salah satunya dengan memberikan workshop terkait gerakan literasi kebudayaan dan kebudayaan. Workshop dilakukan pada hari Senin 3 Agustus 2020. Kegiatan workshop ini diikuti oleh 8 guru dan 1 kepala sekolah. Kegiatan workshop dilakukan sesuai dengan protokol kesehatan.

Kegiatan workshop ini memaparkan terkait pengertian gerakan literasi budaya dan kewarganegaraan. Prinsip gerakan literasi budaya dan kewarganegraan adalah dengan melakukan strategi gerakan. Melalui strategi gerakan literasi, maka pencapaian dalam pembelajaran akan didapat. Pembelajaran yang tepat merupakan kunci dari proses pencapaian hasil (Dimyati, 2002). Workshop ini adalah bagian dari proses refresh maupun menambah wawasan guru dalam gerakan literasi kebudayaan dan kewarganegaraan.

Dalam kegiatan workshop ini guru mendapatkan tambahan wawasan bahwa gerakan literasi yang selama ini guru lakukan dapat lebih difokuskan lagi misalnya literasi budaya dan kewarganegaraan. Sehingga informasi yang didapat siswa dari kegiatan literasi temanya lebih terfokus. Selain itu guru juga dapat mengkondisikan siswa dalam gerakan literasi tidak hanya yang berkaitan dengan tema kegiatan literasi namun guru juga mendapatkan wawasan alternatif pelaksanaan literasi. Dalam kegiatan ini guru juga mendapatkan wawasan untuk dapat lebih sistematis dalam melaksanakan literasi (Uzer, 2001).

Gerakan literasi budaya dan kewarganegaraan ini sangat perlu diberikan bagi siswa SD, karena usia SD merupakan pondasi dari generasi muda. Generasi muda merupakan generasi masa depan dan perlu dibekali dengan pemahaman literasi budaya yang mumpuni agar mampu memperkuat identitas bangsa. Identitas bangsa yang melekat pada kegiatan literasi dapat dilakukan khususnya literasi budaya dan kewarganegaraan yang tidak hanya berkaitan dengan membaca buku. Namun guru juga dapat menggunakan video, lingkungan sekitar yang berkaitan dengan kebudayaan dan ketahaman dan keamanan lingkungan.

Selain itu dengan adanya workshop ini guru juga diberikan wawasan terkait pelaksanaan literasi yang sistematis. Hal ini dilakukan dengan memberikan Standart Operational Prosedure (SOP) pelaksanaan literasi budaya dan kewarganegaraan yang dapat dilakukan oleh guru. Adapun SOP gerakan literasi tersebut yaitu: 1) Guru menentukan tema literasi budaya \& kewarganegaraan, 2) Siswa diberi tugas terkait literasi budaya \& kewarganegaraan, 3) Guru meminta salah satu siswa untuk menyampaikan infomasi yang didapat melalui voice note atau video yang dikirim di grub WhatsApp, 4) Guru mempersilahkan salah satu siswa untuk bertanya, dan 5) Guru memberikan penguatan terkait materi literasi.

Materi literasi yang merupakan bagian suatu kebudayaan bangsa dapat dibungkus dengan suatu gerakan literasi. Gerakan literasi dalam hal terkait kebudayaan dan kewarganegaraan merupakan suatu gerakan kemampuan dalam bersikap kepada lingkungan sekitar. Indonesia merupakan negara yang terdiri dari berbagai macam suku bangsa, agama, adat, budaya maupun kebiasaan. Selain itu Indonesia terdiri berbagai pulau yang dipisahkan oleh laut dan memiliki letak geografi yang berbeda-beda. Hal ini tentu saja 


\section{Volume 72, Nomor 2, Desember 2020}

mempengaruhi perbedaan budaya yang ada di Indonesia.

Indonesia merupakan negara majemuk yang terdiri dari berbagai macam suku, agama, ras, dan adat istiadat. Terbukanya akses antar negara dengan saling bekerja sama juga membuka peluang untuk masuknya pengaruh budaya asing yang mewarnai kebudayaan di Indonesia. Maka, dengan masuknya berbagai budaya global ke Indonesia membuat semakin beragam dan kompleks.

Keberagaman akan memberikan stimulus untuk menumbuhkan dan meningkatkan rasa cinta tanah air serta nasionalisme generasi penerus bangsa melalui literasi kebudayaan dan kewarganegaraan. Hal ini sesuai dengan pernyataan (Hardiansyah dkk: 2017) yang menyatakan bahwa salah satu prinsip gerakan literasi kebudayaan dan kewarganegaraan yaitu nasionalis. Rasa nasionalis atau cinta tanah air membuat martabat negara semakin tinggi dengan sendirinya karena meningkatnya warga negara yang taat aturan.

Taat aturan tidak mengenal masa dan waktu. Meskipun masa pandemi, gerakan literasi juga masih tetap dapat dilaksanakan dengan bimbingan guru. Platform WhatsApp adalah salah satu yang bisa digunakan oleh guru dalam pelaksanaan literasi pada masa pandemi ini. Dengan demikian gerakan literasi yang dilakukan pada masa pandemi dapat mengintegrasikan gerakan literasi sekolah, keluarga, dan masyarakat. Hal ini dapat terbukti gerakan literasi kebudayaan dan kewarganegaraan yang dilakukan pada masa pandemi tentu saja membutuhkan integrasi ketiga lingkungan tersebut, sekolah disini pihak guru yang menentukan SOP dan memantau pelaksanaan literasi kebudayaan dan kewarganegaraan melalu grub WhatsApp. Sedangkan lingkungan rumah dalam hal ini guru bekerjasama dengan orang tua untuk memantau dan memastikan siswa melaksanakan gerakan literasi yang ditugaskan oleh guru. Sedangkan masyarakat yang menyediaka materi terkait literasi budaya dan kewarganengaraan. Hal ini sesuai dengan ranah gerakan literasi yang disampaiakan oleh (Atmazaki, dkk: 2017) yang menyatakan bahwa ranah gerakan literasi yaitu gerakan literasi sekolah, gerakan literasi keluarga, dan gerakan literasi masyarakat.

\section{KESIMPULAN}

Literasi budaya dan kewarganegaraan di sekolah pada masa pandemi tetap dapat dilaksanakan. Hal ini dapat menggunkaan platform grub WhatsApp. Pelaksanaannya dapat dilakukan dengan diawali guru menentukan tema apa yang akan dipelajari siswa dalam kegiatan literasi budaya dan kewarganegaraan. Selanjutnya siswa dapat diberi tugas berkaitan dengan kemampuan menulis dan membaca (literasi) kebudayaan dan kewarganegaraan. Tugas terkait kemampuan tersebut dapat dilakukan dengan memberikan video terkait tema kepada siswa. Kemudian siswa diminta menonton video tersebut. Selain itu kegiatan literasi budaya dan kewarganegaraan dapat dilakukan dengan meminta siswa mengamati lingkungan sekitar yang berkaitan dengan gerakan literasi budaya dan kewarganegaraan. Selanjutnya guru meminta siswa untuk menyampaikan informasi yang didapat melalui voice note atau video yang dikirim melalui grub WhatsApp. Setelah itu guru dapat memberikan siswa untuk bertanya dan memberikan penguatan terkait tema literasi.

\section{REFERENSI}

Atmazaki, dkk. 2017. Panduan Gerakan Literasi Nasional. Jakarta: Kemendikbud.

Dimyati dan Mudjiono. 2002. Belajar dan Pembelajaran. Jakarta: Rineka Cipta.

Direktorat Jenderal Pendidikan Dasar Dan Menengah Kementerian Pendidikan Dan Kebudayaan. 2016. Panduan Gerakan Literasi Sekolah di Sekolah Dasar. Jakarta: Tim Kemendikbud.

Hardiansyah dkk. 2017. Literasi Budaya dan Kewarganegaraan. Jakarta: Kemendukbud.

Marpaung. 2001. Pendekatan Konstektual dan Seni dalam Pembelajaran Matematika. Disampaikan dalam Seminar RME di USD Yogyakarta. 14-15 November 2001.

Miles, M.B., \& Huberman, A.M. 2014. Qualitative Data Analysis, a Sourcebook of New Methods. California: SAGE Publications. 
WAHANA

Volume 72, Nomor 2, Desember 2020

Sugiyono. 2014. Memahami Penelitian Kualitatif. Bandung: Alfabeta.

Uzer Usman M. 2001. Menjadi Guru Profesional. Bandung: Remaja Rosdakarya.

Wina Sanjaya. 2005. Pembelajaran dalam Implikasi Kurikulum Berbasis Kompetensi. Jakarta: Prenada Media. 